\title{
REVERSIBLE INACTIVATION OF THE DORSAL RAPHE NUCLEUS INCREASES MORPHINE-INDUCED ANTINOCICEPTION IN TOLERATED BUT NOT IN NONTOLERATED RATS
}

\author{
Received February 1, 2014
}

We examined possible effects of the state of the dorsal raphe nucleus (DRN) on morphineinduced antinociception in morphine-tolerated and nontolerated rats. Stereotaxically, lidocaine (2\%) was applied to the DRN for its reversible inactivation. On the test day, all animals received $10 \mathrm{mg} / \mathrm{kg}$ morphine $10 \mathrm{~min}$ before the tail-flick test (induction of thermal acute pain), and the maximum antinociceptive effect (MPE) was measured. In the morphinetolerated group, animals preliminarily received everyday introductions of $20 \mathrm{mg} / \mathrm{kg}$ morphine for four consecutive days. There was a significant increase in the MPE (\%) in the lidocainetreated group (with inactivation of the DRN) compared to the control group. However, there was no significant difference in morphine-induced antinociception between the saline- and lidocaine-treated groups. Nonetheless, the antinociceptive responses to morphine (MPE) in morphine-tolerated rats were more significant in animals treated with lidocaine compared to the control group. Our results suggest that lack of GABA in the locus coeruleus, which follows inhibition of serotonin release in the DRN during ablation, may cause adrenergic cellinduced analgesic effects.

Keywords: pain, dorsal raphe nucleus, reversible inactivation, morphine tolerance, lidocaine, locus coeruleus.

\section{INTRODUCTION}

In the dorsal raphe nucleus (DRN) localized in the ventromedial part of the midbrain periaqueductal gray (PAG) [1], various neurotransmitters, including 5-HT (serotonin) and opioids, are released $[2,3]$. There is much evidence showing that the DRN is involved in the mechanisms of pain modulation $[4,5]$, and serotonergic neurons play a major role in these effects $[1,2]$. There are many anatomical and functional connections between the DRN and other parts of the brain $[6,7]$. The locus coeruleus (LC) is one of these regions connected with the DRN [8,9]. Kishi et al. [4] showed that serotonergic neurons of the DRN and noradrenergic neurons of the LC cooperate with each other in monoamine-mediated antinociception. The DRN exerts a much stronger effect on evoked LC

\footnotetext{
Neurophysiology Research Center, Hamadan University of Medical Sciences, Hamadan, Iran.

${ }^{2}$ Neurophysiology Research Center, Urmia University of Medical Sciences, Urmia, Iran.

${ }^{3}$ Neuroscience Research Center, Shahid Beheshti University of Medical Sciences, Tehran, Iran.

Correspondence should be addressed to A. Sarihi

(e-mail: asarihi@yahoo.com).
}

activity than on spontaneous activity in this structure; this may indicate that serotonin exerts presynaptic effects on inbound fibers carrying pain-related information [10]. Inhibitory serotonergic synapses from the raphe were identified in the LC. The DRN potentially provides antagonistic actions on the LC responses to noxious stimuli [10].

Previous studies showed that serotonergic and opioidergic neurons are localized in the DRN, and several studies have been carried out on interactions between these two systems. Serotonin 5-HT receptors regulate the opioid release in the spinal cord [11]. The 5- $\mathrm{HT}_{3}$ receptors induce the release of opioid peptides that could inhibit the release of neurotransmitters regulating the sympathetic tonus and blood pressure [12]. Opioids may mediate behavioral templates induced by incitement of brain $5-\mathrm{HT}_{2}$ receptors $[13,14]$. Some changes should happen in DRN cellular activity after morphine administration due to a possible feedback loop if morphine acts presynaptically on serotonergic synapses [15]. Morphine analgesia decreases in patients who received repeated administration of this agent [16]. Also, the above two systems collaborate with the involvement 
of adrenergic neurons, i.e., the opioidergic and noradrenergic systems intensely interact with each other [17]. In particular, these systems interact significantly when providing intense analgesia at the spinal level [18].

As is known, noradrenergic cells form seven groups in the brain (A1-A7) [19], and one of these groups (A6) is located in the LC [17]. This group is connected with some other brain nuclei related to pain behaviors. The PAG also sends a lot of information to this region [20].

There is evidence that the DRN is responsible for antinociceptive effects. It was shown that post-ictal analgesia decreased under conditions of neurotoxic lesion of the DRN [2]. In another investigation, stimulation of the DRN and some part of the PAG could induce analgesic effects [21]. At the same time, Segal [10] established that the DRN could exert nociceptive effects by inhibitory influences on the LC. According to Wang and Nakai [1], the DRN is considered a nucleus having strong descending and ascending pain inhibitory pathways. The DRN serotonergic activity can be decreased by constant administration of morphine (according to [22]). 8-OH-DPAT, an agonist of $5-\mathrm{HT}_{1 \mathrm{~A}}$ receptors, inhibited morphine-induced tolerance to antinociception influences [23]. There are indications that apoptosis increased in the DRN in the case of long-lasting exposure to morphine [24, 25].

Thus, there are controversial ideas on the mechanisms responsible for DRN involvement in morphine-induced tolerance to pain. This is why we tried to examine the effects of reversible inactivation of the DRN on pain modulation in morphine-tolerant and nontolerant experimental animals.

\section{METHODS}

Animals and Drugs. Adult male albino Wistar rats (body mass 230-280 g) were used in our experiments. Animals were housed under standard vivarium conditions in groups of three per cage at a constant temperature of $22 \pm 2{ }^{\circ} \mathrm{C}$ with a 12/12-h light/dark cycle (lights on at 7:00 a.m.).

Morphine sulfate (Temad, Iran), 2-(diethylamino)$\mathrm{N}$-(2,6-dimethylphenyl) acetamide, and lidocaine (Iran) were dissolved in sterile saline $(0.9 \%)$. Control animals received normal saline as a vehicle.

Stereotaxic Surgery. All surgical procedures were conducted under ketamine/xylazine $(100 \mathrm{mg} / \mathrm{kg}$ ketamine $+10 \mathrm{mg} / \mathrm{kg}$ xylazine, i. p.) anesthesia.
Stainless steel 23-gauge guide cannulae were stereotaxically (Stoelting, USA) implanted in the DRN considering the following coordinates: $\mathrm{AP}=$ $=7.8 \mathrm{~mm}$ caudal to bregma, $\mathrm{Lat}=0.00, \mathrm{DV}=4.5 \mathrm{~mm}$ ventral from the skull surface [26] The cannulae were $11 \mathrm{~mm}$ long, and their tips were $1 \mathrm{~mm}$ above the appropriate injection place. Jeweler screws and dental acrylic cement were applied for securing the cannulae. After the cement was completely hardened, two stainless steel stylets occluded the guide cannulae during the recovery period. Animals were individually housed and allowed to recover for 5-7 days before the experiments. The injection volume was $0.5 \mu \mathrm{l}$ in each side and injection lasted 1 min. The needle was left in place for another $60 \mathrm{sec}$ before they were slowly withdrawn. In shamoperated group, animals received no injections.

Tail-Flick Test. A standard tail-flick analgesiometer apparatus was used for testing the acute thermal pain (IR ray heating). The baseline of the tail-flick latency (TFL) was within a 3-4 sec range, caused by manually setting of the light intensity at about $35 \%$ of the maximum. The equipment was calibrated in order to obtain two consecutive baseline TFLs between 3 and $4 \mathrm{sec}$. The cut-off point was determined as $10 \mathrm{sec}$ to prevent tissue damage [27]. The TFLs (sec) were expressed either as raw data or as a percentage of the maximal possible effect (MPE) calculated from the following formula:

$\mathrm{MPE}=\frac{\text { post-drug latency }(\mathrm{sec})-\text { baseline latency }(\mathrm{sec})}{\text { cut-off value }(\mathrm{sec})-\text { baseline latency }(\mathrm{sec})} \cdot 100 \%$

Experimental Design. A 2\% lidocaine solution was bilaterally administered to the DRN for reversible inactivation of this area. The control group received saline instead of lidocaine. The tail-flick test was performed to measure the intensity of acute pain 15 , 30,45 , and 60 min after administrations.

For estimation of morphine-induced analgesia, morphine $(10 \mathrm{mg} / \mathrm{kg})$ was subcutaneously (s.c.) injected $10 \mathrm{~min}$ before the tail-flick test. The MPE values were calculated for both control and lidocainetreated groups.

To clarify the effects of DRN inactivation on morphine-tolerated rats, such animals received 4 everyday introductions of $20 \mathrm{mg} / \mathrm{kg}$ morphine during four days. The day dose was divided into two equal $(10 \mathrm{mg} / \mathrm{kg})$ doses, which were injected at 8 a.m. and 6 p.m. On the test day, lidocaine was administered to inactivate the DRN [28]. The control group received saline instead of lidocaine. A test dose of $10 \mathrm{mg} / \mathrm{kg}$ 
morphine was injected, and 10 min later the tail flick test was performed. The MPEs were calculated for both control and lidocaine-treated groups.

Histological Verification. At the end of each experiment, the animals were deeply anesthetized with sodium pentobarbital, and $1 \mu 1$ Pontamine sky blue was injected via the injection cannula. The perfusion/ fixation was performed intracardially with saline followed by $10 \%$ formalin/phosphate buffer solution. Then, the brains were removed and post-fixed in the same fixative. Paraffin sections were prepared and stained (hematoxylin + eosin); the location of the cannula was verified [26]. Only the animals with correct cannula placements were included in the data analysis.

Statistical Analysis. The data were analyzed by two-way ANOVA (Factor 1, treatment, and factor 2, time) followed by the Bonferroni test. Oneway ANOVA followed by Newman-Keuls multiple comparisons was used to analyze each independent group. $P$-values below $0.05(P<0.05)$ were considered indications of the statistical significance.

\section{RESULTS}

Effects of DRN Functional Inactivation on Pain Transmission. To determine the effects of the DRN on pain modulation, lidocaine was administrated, and the tail-flick test was performed 15,30, 45, and 60 min after drug administration. The two-way ANOVA test indicated that there is a significant difference between lidocaine- and saline-treated groups. The Bonferroni post-hoc test pointed to significant differences between lidocaine- and saline-treated groups; dramatic increases in the MPE were obvious 15 and $30 \mathrm{~min}$ after administration but not 45 and $60 \mathrm{~min}$ after it (Fig. 1). One-way ANOVA revealed that there were significant increases in the MPE in the lidocaine-treated group 15 and 30 but not 45 and $60 \mathrm{~min}$ after administration. No significant difference was observed in lidocaine-treated animals after administration. We did not see considerable alterations of locomotor activity (the differences were insignificant). These results indicate that functional ablation of the DRN can induce strong analgesia in a time-dependent manner.

Effects of DRN Functional Inactivation on Morphine Analgesia. Effects of the DRN on pain in rats with morphine analgesia were evaluated with DRN inactivation via lidocaine administration. The

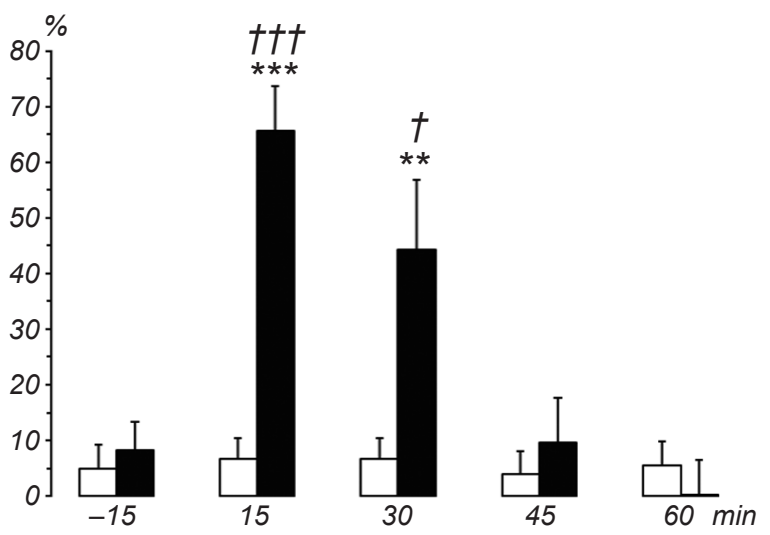

Fig. 1. Effects of reversible inactivation of the dorsal raphe nucleus (DRN) on the maximal possible effect (MPE, \%) as an antinociception index. Lidocaine $(2 \%)$ was administered for DRN inactivation (filled columns), while control-group animals received normal saline (open columns). The tail-flick test was performed $15,30,45$, and $60 \mathrm{~min}$ after drug/saline administration. Means \pm s.e.m. are shown $(n=8)$. $* * P<0.01$ and $* * * P<0.001$ indicate significant differences from the respective 15 -min points before administration of lidocaine or saline; $\uparrow P<0.05$ and $\uparrow \dagger \uparrow P<0.001$ indicate significant differences from the saline group at the $15-\mathrm{min}$ time intervals

Р и с. 1. Впливи оборотної інактивації nucl. raphe dorsalis на індекс інтенсивності антиноцицепції (максимальний можливий ефект, МРЕ, \%).

MPE (\%) was calculated from the data obtained by the tail-flick test and analyzed with the two-way and oneway ANOVA tests.

There were no significant differences between the saline- and lidocaine-treated groups. The MPE values did not differ considerably between the two groups within the entire test time, while the MPE increased significantly after administration in comparison with that before administration in both lidocaineand saline-treated groups (Fig. 2). Modifications of locomotor activity were also insignificant. These results indicate that functional ablation of the DRN exerts no significant effect on the intensity of morphine analgesia.

Effects of DRN Functional Inactivation on Morphine Analgesia in Morphine Tolerated Rats. To clarify the effects of the DRN on morphinetolerated rats, analogous procedures were carried out. The control group received saline instead of lidocaine. Animals were made tolerant to morphine based on the protocol mentioned above. The analyzed data showed that the MPE (\%) was significantly greater in animals treated with lidocaine compared to that in salinetreated rats within the entire period of observation (15 to $60 \mathrm{~min}$ after administration). There was also a significant difference between the values measured 


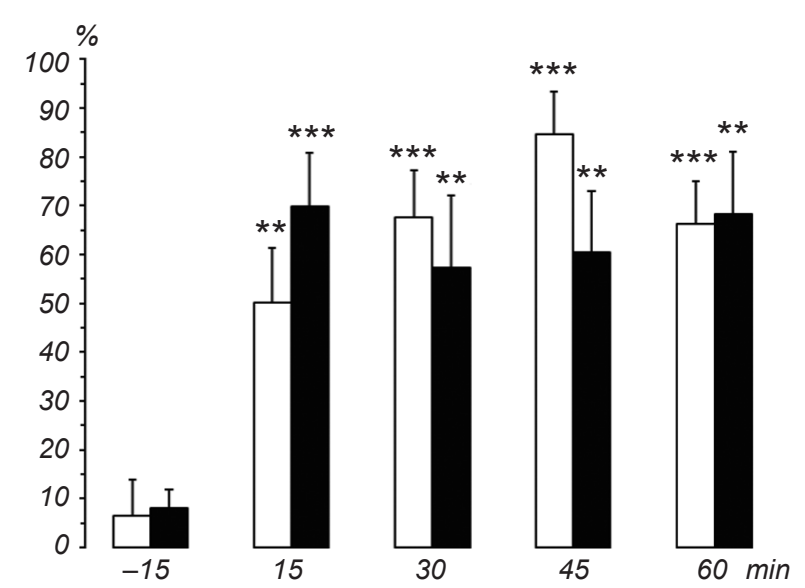

Fig. 2. Effects of reversible inactivation of the dorsal raphe nucleus (DRN) on the intensity of morphine analgesia. Lidocaine (2\%) was administered for DRN inactivation, and control-group animals received normal saline. Morphine $(10 \mathrm{mg} / \mathrm{kg}$, s.c.) was injected 10 min before the tail-flick test. The latter was performed at 15, 30, 45, and $60 \mathrm{~min}$ after drug administration. Designations are similar to those in Fig. 1.

Р и с. 2. Впливи оборотної інактивації nucl. raphe dorsalis на інтенсивність морфінової аналгезії.

pre- and post-lidocaine administration within the entire time interval. In the control group, there was significant difference only at $30 \mathrm{~min}$ from the data before injection (Fig. 3). Alteration of the locomotor activity was not found. These results indicate that
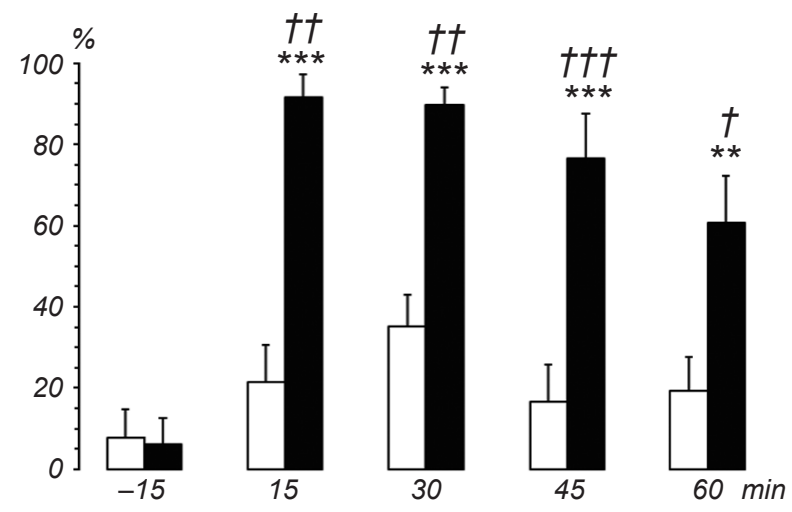

Fig. 3. Effects of reversible inactivation of the dorsal raphe nucleus (DRN) on the intensity of morphine analgesia in morphine-tolerated rats. Animals received everyday s.c. injections of $20 \mathrm{mg} / \mathrm{kg}$ morphine (two injections of $10 \mathrm{mg} / \mathrm{kg}$ per day) during 4 days for induction of morphine tolerance. Tolerant animals received applications of lidocaine or saline into the DRN on the test day. On this day, $10 \mathrm{mg} / \mathrm{kg}$ morphine was injected $10 \mathrm{~min}$ before the tail flick test. Designations are similar to those in Fig. 1.

Р и с. 3. Впливи оборотної інактивації nucl. raphe dorsalis на інтенсивність морфінової аналгезії у щурів, толерантних щодо морфіну. functional ablation of the DRN strongly facilitates morphine analgesia in morphine-tolerant animals.

\section{DISCUSSION}

The data obtained in our experiments indicate that: (i) transient inactivation of the DRN significantly increases the TFL in normal rats; (ii) inactivation of the DRN exerts practically no effect on the intensity of morphine analgesia; (iii) inactivation of the DRN increases the intensity of such analgesia in morphinetolerant rats. Our study showed that inactivation of the DRN provides significant antinociceptive effects in normal rats; in other words, inactivation of the DRN is responsible for relative hyperalgesia mediated by painrelated pathways. The MPE increases significantly during DRN inactivation by lidocaine injection; in 45 min after such injection, the MPE starts to decrease because of reduction of the lidocaine effect.

The LC may mediate the effects of raphe stimulation and nociception. This structure contains a considerable amount of serotonergic inputs that may originate from the DRN [29]; it also contains opioid receptors [30]. The LC-mediated excitatory responses to noxious stimuli were blocked after DRN electrical stimulation; thus, there are, probably, inhibitory serotonergic pathways from the DRN to the LC [10].

There is some evidence demonstrating that the LC contains a lot of GABAergic neurons [31,32]. In the $\mathrm{LC}$, there is also a significant group of noradrenergic cells; this structure is considered a major site of localization of noradrenergic cells in the brain [33]. It was shown experimentally that serotonin increases the GABA release [34]; this is why we suggest that serotonergic pathways in the DRN could induce intensified GABA release in the LC. In such a way, adrenergic cells located in the LC provide an inhibitory effect, and this procedure is capable of reducing the intensity of pain due to activation of the descending inhibitory pain-related system. Therefore, serotonin release from the DRN to the LC is limited during inactivation of the DRN, and the final effect is a decrease in the pain intensity.

In our study, DRN inactivation exerted no significant effect on rats with morphine analgesia; there were no significant differences between the saline-treated and lidocaine-treated groups. According to some evidence, morphine can inhibit GABA release in the LC $[35,36]$; so, adrenergic neurons could decrease pain via this mechanism. The target of morphine is a population of 
GABAergic cells in the LC. This is why the activity of DRN neurons would not be affected by morphine [37]. Therefore, we can conclude that the serotonin release from the DRN could not influence GABA release because the morphine level is high enough to block this process. There is evidence confirming our results; Pan et al. [36] reported that opioids could drive LC neurons via presynaptic inhibition of GABAergic inputs. Noxious stimuli can excite LC cells, while morphine inhibits these units $[35,38]$. The lesion of noradrenergic LC neurons can intensify inflammatory hypersensitivity [39], which is proof of the analgesic role of noradrenergic cells in this mechanism.

In morphine-tolerant rats, analgesic effects were observed in the course of transient inactivation of the DRN. The differences between the saline-treated and lidocaine-treated groups were significant from this aspect. Probably, GABA released in the LC wouldn't inhibit anymore by morphine because the tolerance was induced. Probably, serotonin released from the DRN could display its GABA release-inducing properties in the LC of tolerant animals. The reduced intensity of analgesia in patients who received repeated administration of morphine may be a consequence of the development of pharmacological tolerance to morphine and tolerance-associated hyperalgesia [16]. In our respective experimental group, the analgesic effect was preserved for a longer time. It was manifested even 45 min after lidocaine administration to the DRN. This situation may be related to interaction between the opioid and serotonergic systems; there is much evidence confirming this conclusion. Activation of $5-\mathrm{HT}_{1 \mathrm{~A}}$ receptors could block synthesis and release of opioid peptides in the respective spinal neuronal systems [11]. Fregoneze et al. [12] showed that the opioid and serotonergic systems intensely functionally interact with each other in a few parts of the brain. Opioid withdrawal behavior decreases due to administration of ondansetron, a selective $5-\mathrm{HT}_{3 \mathrm{~A}}$ antagonist [40]. Some papers reported that opioids help serotonin-mediated mechanisms to provide higher efficacy. For example, Nozaki and Kamei [41] declared that serotonin and some selective serotonin reuptake inhibitors may show antinociceptive effects, and opioids are probably involved in the latter. In other studies, it was shown that the analgesic effects of serotonergic agonists could be inhbited by naloxone (a non-selective opioid receptor antagonist), which represents possible involvement of opioids in serotonin-induced antinociception [12,42]. Blocking of all opioid receptors could abrogate hypotension caused by $5-\mathrm{HT}_{3}$ receptor-dependent effects, indicating that activation of opioid receptors is required for the development of this phenomenon [12]. Therefore, we suggest that tolerance to morphine reduces the functions of serotonin released from the DRN and affecting GABAergic neurons in the LC. This may be the reason for prolongation of the analgesic effect (45 min after lidocaine administration) in morphinetolerant animals.

According to some studies mentioned above, serotonin is responsible for analgesic effects, while in our study we observed pain-intensifying effects of this agent. Further investigations are needed to reveal more details of the mechanisms involved in this circuit.

Therefore, we conclude that the DRN plays an important role in pain modulation. It influences morphine analgesia in morphine-tolerant animals, and DRN-born serotonergic projections to the nociceptive pathways are responsible for this effect. The neural mechanisms of the respective circuits should be elucidated in more detail.

Acknowledgement. This study was supported by a grant from the Neurophysiology Research Center, Hamadan University of Medical Sciences, Hamadan, Iran.

All experiments were performed in accordance with the Guide for the Care and Use of Laboratory Animals (National Institutes of Health Publication No. 80-23, revised 1996) and were approved by the Research and Ethics Committee of the Hamadan University of Medical Sciences, Hamadan, Iran.

The authors of this study, A. Sarihi, B. Heshmatian, P. Pahlevani, A. Komaki, and A. Haghparast, confirm that the research and publication of the results were not associated with any conflicts regarding commercial or financial relations, relations with organizations and/or individuals who may have been related to the study, and interrelations of co-authors of the article.

\section{A. Саріхі $^{1}$, Б. Хешматян ${ }^{2}$, П. Пахлевані ${ }^{1,3}$, A. Комакі $^{1}$, A. Xaznapaci ${ }^{3}$}

ОБОРОТНА IНАКТИВАЦІЯ NUCL. RAPHE DORSALIS ПОСИЛЮЄ ІНДУКОВАНЕ МОРФІНОМ ЗНЕБОЛЕННЯ У ТОЛЕРАНТНИХ, АЛЕ НЕ У НЕТОЛЕРАНТНИХ ЩУРІВ

\footnotetext{
${ }^{1}$ Нейрофізіологічний дослідницький центр Хамаданського медичного університету (Іран).

${ }^{2}$ Нейрофізіологічний дослідницький центр Медичного університету Урмії (Іран).

${ }^{3}$ Нейрофізіологічний дослідницький центр Медичного університету Шахіда Бехешті, Тегеран (Іран).
} 
$\mathrm{P}$ е 3 ю м е

Ми досліджували можливі впливи стану nucl. raphe dorsalis $(D R N)$ на індуковане морфіном знеболення у щурів, толерантних щодо морфіну. 3 використанням стереотаксичної техніки лідокаїн (2\%) уводили в $D R N$, що зумовлювало оборотну інактивацію останнього. В день тестування тваринам уводили морфін за 10 хв перед тестом відсмикування хвоста (індукції гострого термального болю) та розраховували максимальний антиноцицептивний ефект (МАЕ\%). У групі тварин 3 толерантністю до морфіну в три послідовні доби отримували попередні ін'єкції останнього. В групі 3 ін' єкціями лідокаїну (з інактивацією $D R N$ ) значення МАE\% були істотно збільшеними порівняно з контролем. Не спостерігалося, проте, істотних відмінностей між рівнями індукованого знеболення в групах тварин, котрим уводили фізрозчин та лідокаїн. У той же час антиноцицептивні відповіді на введення морфіну (МАЕ\%) у тварин із толерантністю до морфіну були істотнішими у тих щурів, котрим уводили лідокаїн, ніж у контрольних. Наші результати дозволяють думати, що дефіцит ГАМК у locus coeruleus після гальмування вивільнення серотоніну в $D R N$ внаслідок функціонального виключення останнього може зумовлювати аналгезивні ефекти, опосередковані адренергічними клітинами.

\section{REFERENCES}

1. Q. P. Wang and Y. Nakai, "The dorsal raphe: an important nucleus in pain modulation," Brain Res. Bull., 34, No. 6, 575585 (1994).

2. R. L. Freitas, G. S. Bassi, A. M. de Oliveira, and N. C. Coimbra, "Serotonergic neurotransmission in the dorsal raphe nucleus recruits in situ $5-\mathrm{HT}(2 \mathrm{~A} / 2 \mathrm{C})$ receptors to modulate the post-ictal antinociception," Exp. Neurol., 213, No. 2, 410418 (2008).

3. B. L. Jacobs and E. C. Azmitia, "Structure and function of the brain serotonin system," Physiol. Rev., 72, No. 1, 165-229 (1992).

4. R. Kishi, R. Bongiovanni, T. R. de Nadai, et al., "Dorsal raphe nucleus and locus coeruleus neural networks and the elaboration of the sweet-substance-induced antinociception," Neurosci. Lett., 395, No. 1, 12-17 (2006).

5. 5. C. I. Miyase, R. Kishi, R. L. de Freitas, et al., "Involvement of pre- and post-synaptic serotonergic receptors of dorsal raphe nucleus neural network in the control of the sweet-substanceinduced analgesia in adult Rattus norvegicus (Rodentia, Muridae),"Neurosci. Lett., 379, No. 3, 169-173 (2005).

6. M. L. Mamede Rosa, M. A. Oliveira, R. B. Valente, et al., "Pharmacological and neuroanatomical evidence for the involvement of the anterior pretectal nucleus in the antinociception induced by stimulation of the dorsal raphe nucleus in rats," Pain, 74, Nos. 2/3, 171-179 (1998).

7. Q. P. Ma and J. S. Han, "Neurochemical and morphological evidence of an antinociceptive neural pathway from nucleus raphe dorsalis to nucleus accumbens in the rabbit," Brain Res. Bull., 28, No. 6, 931-936 (1992).
8. M. A. Kim, H. S. Lee, B. Y. Lee, and B. D. Waterhouse, "Reciprocal connections between subdivisions of the dorsal raphe and the nuclear core of the locus coeruleus in the rat," Brain Res., 1026, No. 1, 56-67 (2004).

9. H. S. Lee, M. A. Kim, and B. D. Waterhouse, "Retrograde double-labeling study of common afferent projections to the dorsal raphe and the nuclear core of the locus coeruleus in the rat," J. Comp. Neurol., 481, No. 2, 179-193 (2005).

10. M. Segal, "Serotonergic innervation of the locus coeruleus from the dorsal raphe and its action on responses to noxious stimuli," J. Physiol., 286, 401-415 (1979).

11. B. Song, W. Chen, and J. C. Marvizon, "Inhibition of opioid release in the rat spinal cord by serotonin 5-HT(1A) receptors," Brain Res., 1158, 57-62 (2007).

12. J. B. Fregoneze, E. F. Oliveira, V. F. Ribeiro, et al., "Multiple opioid receptors mediate the hypotensive response induced by central 5-HT(3) receptor stimulation," Neuropeptides, 45, No. 3, 219-227 (2011)

13. S. J. Corne, R. W. Pickering, and B. T. Warner, "A method for assessing the effects of drugs on the central actions of 5-hydroxytryptamine," Br. J. Pharmacol. Chemother, 20, No. 1, 106-120 (1963).

14. J. Vetulani, B. Bednarczyk, K. Reichenberg, and A. Rokosz, "Head twitches induced by LSD and quipazine: similarities and differences," Neuropharmacology, 19, No. 2, 155-158 (1980).

15. G. K. Aghajanian, "Chemical-feedback regulation of serotonincontaining neurons in brain," Ann. New York Acad. Sci., 193, Aug., 86-94 (1972).

16. D. J. Mayer, J. Mao, J. Holt, and D. D. Price, "Cellular mechanisms of neuropathic pain, morphine tolerance, and their interactions," Proc. Natl. Acad. Sci. USA, 96, No. 14, 77317736 (1999).

17. A. Pertovaara, "Noradrenergic pain modulation," Prog. Neurobiol., 80, No. 2, 53-83 (2006).

18. I. Nakagawa, K. Omote, L. M. Kitahata, et al., "Serotonergic mediation of spinal analgesia and its interaction with noradrenergic systems," Anesthesiology, 73, No. 3, 474-478 (1990).

19. A. Dahlstroem and K. Fuxe, "Evidence for the existence of monoamine-containing neurons in the central nervous system. I. Demonstration of monoamines in the cell bodies of brain stem neurons," Acta Physiol. Scand., Suppl. 232, 1-55 (1964).

20. D. Bajic and H. K. Proudfit, "Projections of neurons in the periaqueductal gray to pontine and medullary catecholamine cell groups involved in the modulation of nociception," $J$. Comp. Neurol., 405, No. 3, 359-379 (1999).

21. V. Fardin, J. L. Oliveras, and J. M. Besson, "A reinvestigation of the analgesic effects induced by stimulation of the periaqueductal gray matter in the rat. I. The production of behavioral side effects together with analgesia," Brain Res., 306, Nos. 1/2, 105-123 (1984).

22. T. Jolas and G. K. Aghajanian, "Opioids suppress spontaneous and NMDA-induced inhibitory postsynaptic currents in the dorsal raphe nucleus of the rat in vitro," Brain Res., 755, No. 2, 229-245 (1997).

23. M. Charkhpour, A. R. Nayebi, Y. Doustar, and K. Hassanzadeh, "8-OH-DPAT prevents morphine-induced apoptosis in rat dorsal raphe nucleus: a possible mechanism for attenuating morphine tolerance," Anesth. Analg., 111, No. 5, 1316-1321 (2010)

24. J. Mao, B. Sung, R. R. Ji, and G. Lim, "Neuronal apoptosis 
associated with morphine tolerance: evidence for an opioidinduced neurotoxic mechanism," J. Neurosci., 22, No. 17, 7650-7661 (2002).

25. K. Hassanzadeh, B. Habibi-as1, L. Roshangar, et al., "Intracerebroventricular administration of riluzole prevents morphine-induced apoptosis in the lumbar region of the rat spinal cord," Pharmacol. Rep., 62, No. 4, 664-673 (2010).

26. G. Paxinos and C. Watson: The Rat Brain in Stereotaxic Coordinates, Elsevier/Acad. Press, New York (2007).

27. A. Haghparast and L. Ahmad-Molaei, "Effects of electrolytic lesion of dorsolateral periaqueductal gray on analgesic response of morphine microinjected into the nucleus cuneiformis in rat," Neurosci. Lett., 451, No. 2, 165-169 (2009).

28. F. Darvishzadeh-Mahani, S. Esmaeili-Mahani, G. Komeili, et al., "Ginger (Zingiber officinale Roscoe) prevents the development of morphine analgesic tolerance and physical dependence in rats," J. Ethnopharmacol., 141, No. 3, 901-907 (2012).

29. M. Palkovits, M. Brownstein, and J. M. Saavedra, "Serotonin content of the brain stem nuclei in the rat," Brain Res., 80, No. 2, 237-249 (1974).

30. C. B. Pert, M. J. Kuhar, and S. H. Snyder, "Opiate receptor: autoradiographic localization in rat brain," Proc. Natl. Acad. Sci. USA, 73, No. 10, 3729-3733 (1976).

31. J. Zezula, R. Cortes, A. Probst, and J. Palacios, "Benzodiazepine receptor sites in the human brain: autoradiographic mapping," Neuroscience, 25, No. 3, 771-795 (1988).

32. J. Luque, P. Malherbe, and J. Richards, "Localization of $\mathrm{GABA}_{\mathrm{A}}$ receptor subunit mRNAs in the rat locus coeruleus," Mol. Brain Res., 24, No. 1, 219-226 (1994).

33. U. Ungerstedt, "Stereotaxic mapping of the monoamine pathways in the rat brain," Acta Physiol. Scand., Suppl. 367, 1-48 (1971).
34. K. Hayashida, M. Kimura, M. Yoshizumi, et al., "Ondansetron reverses antihypersensitivity from clonidine in rats after peripheral nerve injury: role of $\gamma$-aminobutyric acid in $\alpha 2$ adrenoceptor and 5-HT3 serotonin receptor analgesia," Anesthesiology, 117, No. 2, 389-398 (2012).

35. J. Korf, B. S. Bunney and G. K. Aghajanian, "Noradrenergic neurons: morphine inhibition of spontaneous activity," Eur. J. Pharmacol., 25, No. 2, 165-169 (1974).

36. Y. Z. Pan, D. P. Li, S. R. Chen, and H. L. Pan, "Activation of mu-opioid receptors excites a population of locus coeruleusspinal neurons through presynaptic disinhibition," Brain Res., 997, No. 1, 67-78 (2004).

37. H. J. Haigler, "Morphine: ability to block neuronal activity evoked by a nociceptive stimulus," Life Sci., 19, No. 6, 841857 (1976).

38. S. J. Bird and M. J. Kuhar, "Iontophoretic application of opiates to the locus coeruleus," Brain Res., 122, No. 3, 523533 (1977).

39. M. Tsuruoka and W. D. Willis Jr., "Bilateral lesions in the area of the nucleus locus coeruleus affect the development of hyperalgesia during carrageenan-induced inflammation," Brain Res., 726, Nos. 1/2, 233-236 (1996).

40. L. F. Chu, D. Y. Liang, X. Li, et al., "From mouse to man: the 5-HT3 receptor modulates physical dependence on opioid narcotics," Pharmacogen. Genom., 19, No. 3, 193-205 (2009).

41. C. Nozaki and J. Kamei, "Possible involvement of opioidergic systems in the antinociceptive effect of the selective serotonin reuptake inhibitors in sciatic nerve-injured mice," Eur. J. Pharmacol., 552, Nos. 1/3, 99-104 (2006).

42. G. C. Kwiat and A. I. Basbaum, "The origin of brainstem noradrenergic and serotonergic projections to the spinal cord dorsal horn in the rat," Somatosens. Mot. Res., 9, No. 2, 157173 (1992). 